\title{
Ethanol and food deprivation induced enhancement of hepatotoxicity in rats given carbon tetrachloride at low concentration
}

\author{
H Ikatsu, T Okino, T Nakajima
}

\begin{abstract}
Effects of chronic ethanol consumption and one day food deprivation on the hepatotoxicity of low dose carbon tetrachloride $\left(\mathrm{CCl}_{4}\right.$; 0 to $100 \mathrm{ppm}$ inhalation for eight hours) in rats were investigated by using biochemical and histopathological methods. Liver malondialdehyde (MDA) contents were significantly increased by exposure to $5 \mathrm{ppm}$ to $50 \mathrm{ppm} \mathrm{CCl}_{4}$ in ethanol treated rats or by exposure to 25 ppm to $50 \mathrm{ppm} \mathrm{CCl}_{4}$ in food deprived rats but not in rats without ethanol or food deprivation. The MDA concentrations reached a maximum at $10 \mathrm{ppm}$ and $50 \mathrm{ppm} \mathbf{C C l}_{4}$ in ethanol treated and food deprived rats, respectively, and decreased to the non-exposed concentration at $100 \mathrm{ppm} \mathrm{CCl}_{4}$. At $\geqslant 50$ ppm $\mathrm{CCl}_{4}$ plasma MDA contents increased significantly only in ethanol treated rats. None of the exposure concentrations influenced plasma glutamic-oxaloacetic transamidase (GOT) and glutamic-pyruvic transaminase (GPT) activities in rats that were only exposed to $\mathrm{CCl}_{4}$ whereas exposure to 10 ppm or higher concentrations combined with ethanol increased both activities. To a lesser extent food deprivation combined with exposure to $\geqslant 25 \mathrm{ppm} \mathrm{CCl}_{4}$ had the same effect. No histopathological changes were found in the liver of rats exposed to $\leqslant 10 \mathrm{ppm} \mathrm{CCl}_{4}$, and only a few ballooned hepatocytes were seen in centrilobular areas when exposure was 25 ppm or higher. The presence of ballooned hepatocytes became a regular feature of mid-zonal areas in ethanol treated rats and in the centrilobular areas of food deprived rats after exposure to $\leqslant 10$ and $\leqslant 25 \mathrm{ppm} \mathrm{CCl}_{4}$ respectively. Necrotic hepatocytes were seen in centrilobular areas in liver from ethanol treated and food deprived rats when exposure to $\mathrm{CCl}_{4}$ was $\geqslant 25 \mathrm{ppm}$ and
\end{abstract}

Department of Hygiene, Shinshu University School of Medicine, Japan

H Ikatsu, T Okino, T Nakajima $\geqslant 50$ ppm respectively. These results indicate that consumption of ethanol and food deprivation potentiate $\mathrm{CCl}_{4}$ induced hepatic damage even at low concentrations of $\mathbf{C C l}_{4}$ by promoting lipid peroxidation. Thus heavy drinking may be a risk factor for $\mathrm{CCl}_{4}$ induced hepatic damage even though the $\mathrm{CCl}_{4}$ concentration is as low as the threshold limit value.

Carbon tetrachloride $\left(\mathrm{CCl}_{4}\right)$, which was an extensively used industrial solvent has been progressively replaced by solvents such as trichloroethylene and 1,1,1-trichloroethane, which are considered to have lower hepatotoxicity or carcinogenicity. ${ }^{1-3}$ Thus the number of industrial workers exposed to $\mathrm{CCl}_{4}$ is decreasing. On the other hand, the exposure of workers to $\mathrm{CCl}_{4}$ or chloroform is relatively high when they are engaged in the treatment of chemical waste. ${ }^{4}$

It is widely accepted that $\mathrm{CCl}_{4}$ is metabolically activated by hepatic microsomal cytochrome P-450 mediated reactions to the trichloromethyl radical. ${ }^{5-7}$ Several different forms of cytochrome P-450 have been isolated and characterised. ${ }^{89}$ One of the P-450 isozymes, $\mathrm{P}-450 \mathrm{j}$ (P-450 IIE1) induced by ethanol or food deprivation, ${ }^{1011}$ contributes to the metabolism of $\mathrm{CCl}_{4}{ }^{12}$ and other solvents. ${ }^{13-15}$ Therefore, it is of interest to know whether consumption of ethanol and food deprivation potentiate the hepatotoxicity at threshold limit values (TLVs) or lower of $\mathrm{CCl}_{4}$.

Threshold limit values of $\mathrm{CCl}_{4}$ provided by the American Conference of Governmental Industrial Hygienists (ACGIH) and by the Japan Association of Industrial Health are $5 \mathrm{ppm}$ and $10 \mathrm{ppm}$ respectively. ${ }^{1617}$ It is difficult to extrapolate the doseresponse relation in $\mathrm{CCl}_{4}$ induced hepatotoxicity from the high concentrations used in animal studies to the low concentrations generally encountered by man in the workplace. ${ }^{18}$ Therefore, the doseresponse relation of inhalation exposure at low concentration must be investigated when trying to determine a TLV of exposure concentration for man. In the present study, we investigated the dose- 
response relations of $\mathrm{CCl}_{4}$ induced hepatic damage in chronic ethanol treated and one day food deprived rats with biochemical and histopathological methods.

\section{Materials and methods}

ANIMALS AND DIETS

Male Wistar rats six weeks old were purchased from Nippon SLC Co, Shizuoka, Japan. The animals were housed individually in stainless steel cages. The environmental temperature was kept at $20 \pm 2^{\circ} \mathrm{C}$ with an alternating 12 hour light dark cycle. After being placed on a commercial solid diet (Clea CE-2, Nippon Clea, Tokyo) and water for two weeks, rats were switched to liquid diet.

Eighty rats were divided into three groups: two groups were fed $80 \mathrm{ml}$ of basal diet and the third group $80 \mathrm{ml}$ of ethanol diet daily at 1600 for three weeks. The basal diet, prepared according to the recipe of DeCarli and Liever, ${ }^{19}$ contained $3.47 \mathrm{~g}$ casein, $12.0 \mathrm{~g}$ sucrose, $41 \mathrm{mg}$ L-cystine, $25 \mathrm{mg} \mathrm{DL}$ methionine, $2 \mathrm{~g}$ oil (olive:corn $=4: 1$ ), $212 \mathrm{mg}$ ethyl linoleate, $407 \mathrm{mg}$ vitamin mixture, $2 \mathrm{mg}$ DL- $\alpha-$ tocopherol, $813 \mathrm{mg}$ mineral mixture and $212 \mathrm{mg}$ carragheenin per $80 \mathrm{ml}$. The ethanol diet was made by adding $2.0 \mathrm{~g}$ of ethanol to $80 \mathrm{ml}$ of basal diet and reducing sucrose content to $4.0 \mathrm{~g}$. Half of the rats on the basal diet, which formed the food deprived group, received only water on the day before exposure to $\mathrm{CCl}_{4}$.

DOSE-RESPONSE EXPERIMENT WITH $\mathrm{CCL}_{4}$

Rats of all three groups were exposed to $0 \mathrm{ppm}$, $5 \mathrm{ppm}, 10 \mathrm{ppm}, 25 \mathrm{ppm}, 50 \mathrm{ppm}$, or $100 \mathrm{pm} \mathrm{CCl}_{4}$ for eight hours (800-1600) in a dynamic air flow chamber (volume 360 1). Carbon tetrachloride was introduced quantitatively to the chamber with a microfeeder (KN model, Natsume Seisakusho, Tokyo). Concentration in the chamber was monitored every 15-30 minutes by gas chromatography with a flame ionisation detector (163 type, Hitachi, Tokyo). From the end of $\mathrm{CCl}_{4}$ exposure to killing none of the animals were given food, but water was available.

\section{THE EFFECT OF AMOUNT OF ETHANOL ON $\mathrm{CCL}_{4}$ HEPATOTOXICITY}

Liquid diets containing differing amounts of ethanol were freshly made by adding $0,1.0,1.5$ or $2 \mathrm{~g}$ ethanol to $80 \mathrm{ml}$ basal diet. Sixteen male rats were divided into four equal groups, each group being fed a different ethanol base ( $80 \mathrm{ml}$ dosed diet for each rat) for three weeks. After three weeks rats were exposed to $10 \mathrm{ppm} \mathrm{CCl}_{4}$ for eight hours (800-1600) according to the method described above.

\section{BIOCHEMICAL DETERMINATIONS}

All rats were killed by decapitation 22 hours after ending exposure to $\mathrm{CCl}_{4}$. Blood was collected and liver, kidneys, testicles, and lungs were taken. A part of the liver was cut off for histopathological examination. The remaining liver, perfused with cold $1 \cdot 15 \%$ $\mathrm{KCl}$ via the portal vein, and other organs without perfusion were homogenised in ice cold $1.15 \% \mathrm{KCl}$ solution with a Potter-Elvehjem homogeniser. Lipid peroxide concentration in each tissue was measured indirectly by determing thiobarbituric acid (TBA)positive reactants according to the method of

Table 1 Effect of exposure to $C C l$, on plasma transaminase activity and $M D A$ concentration

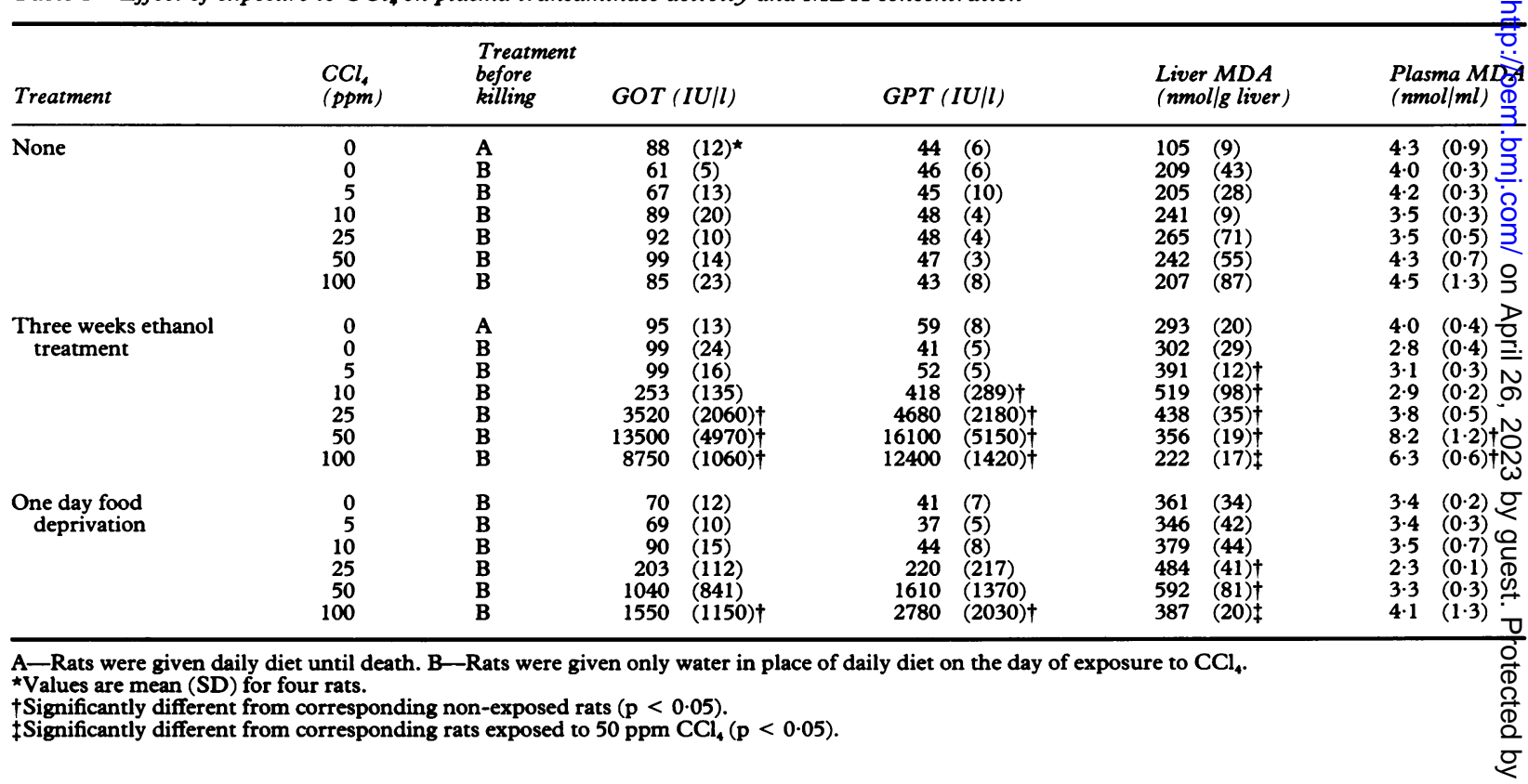


Uchiyama and Mihara ${ }^{20}$ and determined in plasma by the method of Jose and Slater. ${ }^{21}$ The content of TBA reactants was expressed in terms of malondialdehyde (MDA) concentration using 1,1,3,3-tetraethoxypropane as a standard. ${ }^{22}$ Activities of plasma glutamic-oxaloacetic transaminase (GOT) and glutamic-pyruvic transaminase (GPT) were determined enzymatically by measuring the rate of NADH disappearance using Boehringer Mannheim kits. Triglyceride was determined by the acetylacetone method using Wako Pure Chemical kits (Wako Pure Chemicals, Osaka, Japan).

\section{HISTOPATHOLOGY}

For histopathological examinations, liver was fixed in $10 \%$ formalin buffer solution ( $\mathrm{pH} 7 \cdot 4$ ), and sections were stained with haematoxylin-eosin.

Quantitative analysis of hepatic damage (necrosis and ballooning degeneration of hepatocytes) induced by $\mathrm{CCl}_{4}$ was performed by the method of Mitchell et $a l^{23}$ and Hewitt et al. ${ }^{24}$ Ten hexogonal lobules were chosen randomly for each liver section. The distance from the central vein to the periportal area was divided into three parts per lobule to define arbitrarily the centrilobular, mid-zonal, and periportal areas. Scanning was performed in each area per lobule. In each field, the tissue element immediately beneath each of the 16 points of reference was termed a "hit"; thus 16 hits were examined per field. A total of 480 hits ( 160 hits in each area of the lobule) was examined in each section. The hits were categorised as (1) normal parenchymal hepatocyte; (2) ballooned parenchymal hepatocyte; (3) necrotic parenchymal hepatocyte; and (4) other cellular structures. Hits on each of the first three categories were recorded and expressed as a percentage of the total number of hepatocytes examined in that area.

\section{STATISTICAL ANALYSIS}

Statistical analysis was by analysis of variance. When significant differences were found among groups, means were tested by Student's $t$ test. The 0.05 level of probability was used as the criterion of significance. A logarithmic transformation was applied to plasma GOT and GPT activities before statistical analysis.

\section{Results}

\section{PLASMA TRANSAMINASE ACTIVITY}

Carbon tetrachloride did not influence the plasma GOT and GPT activities in non-treated rats at any concentration, but increased both the activities at 10 ppm or higher in ethanol treated rats, and at $25 \mathrm{ppm}$ or higher in one day food deprived rats (table 1 ).

\section{LIPID PEROXIDE IN LIVER AND PLASMA}

Chronic ethanol treatment and one day food deprivation increased liver MDA content by threefold and twofold respectively compared with non-treated rats. One-day food deprivation of ethanol treated rats, however, did not cause further increases in concentrations of liver MDA (table 1).

Carbon tetrachloride did not affect MDA concentrations in kidneys, lungs, and testicles of any rat (data not shown), or in the liver of rats without additional treatment. In ethanol treated rats, the liver MDA concentration was significantly increased at $\mathrm{CCl}_{4}$ concentrations of 5 to $50 \mathrm{ppm}$ but not at a

Table 2 Effect of exposure to $\mathrm{CCl}_{4}$ on liver triglyceride concentration and ratio of liver to body weight

\begin{tabular}{|c|c|c|c|c|c|c|c|c|}
\hline \multirow{2}{*}{$\begin{array}{l}\text { Treatment } \\
\text { None }\end{array}$} & \multirow{2}{*}{$\begin{array}{c}C C l_{4} \\
(p p m)\end{array}$} & \multirow{2}{*}{$\begin{array}{l}\begin{array}{l}\text { Treatment } \\
\text { before } \\
\text { killing }\end{array} \\
\text { A } \\
\text { B } \\
\text { B } \\
\text { B } \\
\text { B } \\
\text { B } \\
\text { B }\end{array}$} & \multicolumn{2}{|c|}{$\begin{array}{l}\text { Triglyceride } \\
\text { (mg/g liver) }\end{array}$} & \multicolumn{2}{|c|}{$\begin{array}{l}\text { Liver:body weight } \\
(w / w(\%))\end{array}$} & \multicolumn{2}{|c|}{ Body weight $(g)$} \\
\hline & & & $\begin{array}{r}22 \cdot 8 \\
9 \cdot 3 \\
10 \cdot 6 \\
12 \cdot 2 \\
18 \cdot 5 \\
22 \cdot 7 \\
44.5\end{array}$ & $\begin{array}{l}(3.4)^{\star} \\
(1.0) \\
(1.6) \\
(0.9) \dagger \\
(4.4) \dagger \\
(3.5) \dagger \\
(6.6) \dagger\end{array}$ & $\begin{array}{l}4.05 \\
3 \cdot 14 \\
3 \cdot 36 \\
3 \cdot 22 \\
3 \cdot 24 \\
3 \cdot 25 \\
3 \cdot 29\end{array}$ & $\begin{array}{l}(0.13) \\
(0.13) \\
(0.08) \\
(0.09) \\
(0.08) \\
(0.07) \\
(0.10)\end{array}$ & $\begin{array}{l}291 \\
280 \\
300 \\
274 \\
277 \\
267 \\
266\end{array}$ & $\begin{array}{l}(10) \\
(7) \\
(16) \\
(7) \\
(9) \\
(5) \\
(13)\end{array}$ \\
\hline $\begin{array}{l}\text { Three weeks ethanol } \\
\text { treatment }\end{array}$ & $\begin{array}{r}0 \\
0 \\
5 \\
10 \\
25 \\
50 \\
100\end{array}$ & $\begin{array}{l}\text { A } \\
\text { B } \\
\text { B } \\
\text { B } \\
\text { B } \\
\text { B } \\
\text { B }\end{array}$ & $\begin{array}{r}11 \cdot 5 \\
6 \cdot 4 \\
6 \cdot 8 \\
12.9 \\
14 \cdot 6 \\
20 \cdot 3 \\
24 \cdot 8\end{array}$ & $\begin{array}{l}(1 \cdot 1) \\
(1 \cdot 1) \\
(0.4) \\
(3 \cdot 4) \dagger \\
(2 \cdot 5) \dagger \\
(3.2) \dagger \\
(1.5) \dagger\end{array}$ & $\begin{array}{l}3.58 \\
2.93 \\
3.01 \\
3.15 \\
3.52 \\
3.83 \\
3.80\end{array}$ & $\begin{array}{l}(0.17) \\
(0.03) \\
(0.09) \\
(0.17) \\
(0.08) \dagger \\
(0.13) \dagger \\
(0.13) \dagger\end{array}$ & $\begin{array}{l}247 \\
236 \\
282 \\
233 \\
229 \\
219 \\
217\end{array}$ & $\begin{array}{l}(14) \\
(7) \\
(8) \\
(7) \\
(11) \\
(15) \\
(11)\end{array}$ \\
\hline $\begin{array}{l}\text { One day food } \\
\text { deprivation }\end{array}$ & $\begin{array}{r}0 \\
5 \\
10 \\
25 \\
50 \\
100\end{array}$ & $\begin{array}{l}\mathbf{B} \\
\mathbf{B} \\
\mathbf{B} \\
\mathbf{B} \\
\mathbf{B} \\
\mathbf{B}\end{array}$ & $\begin{array}{l}18 \cdot 1 \\
19 \cdot 6 \\
25 \cdot 7 \\
31 \cdot 1 \\
17 \cdot 9 \\
24 \cdot 6\end{array}$ & $\begin{array}{l}(1 \cdot 4) \\
(1 \cdot 5) \\
(2 \cdot 2) \dagger \\
(1 \cdot 7) \dagger \\
(4 \cdot 3) \\
(1 \cdot 8) \dagger\end{array}$ & $\begin{array}{l}2 \cdot 51 \\
2 \cdot 79 \\
2 \cdot 78 \\
3 \cdot 01 \\
3 \cdot 12 \\
3 \cdot 14\end{array}$ & $\begin{array}{l}(0.04) \\
(0.09) \dagger \\
(0.06) \dagger \\
(0.11) \dagger \\
(0.22) \dagger \\
(0.30) \dagger\end{array}$ & $\begin{array}{l}274 \\
259 \\
271 \\
257 \\
256 \\
235\end{array}$ & $\begin{array}{l}(13) \\
(10) \\
(6) \\
(7) \\
(18) \\
(13)\end{array}$ \\
\hline
\end{tabular}

For explanations, see footnote to table 1. 
concentration of $100 \mathrm{ppm}$. The increase reached a maximum at $10 \mathrm{ppm} \mathrm{CCl}_{4}$. In one day food deprived rats, no significant increase in concentration of liver MDA was found up to $25 \mathrm{ppm} \mathrm{CCl}_{4}$, whereas it increased liver MDA concentration at 25 and $50 \mathrm{ppm}$ but not at $100 \mathrm{ppm}$. These results indicate that ethanol treatment and one day food deprivation enhanced the hepatic accumulation of lipid peroxides at low concentrations of $\mathrm{CCl}_{4}$.

Plasma MDA concentrations were raised only in ethanol treated rats exposed to 50 and $100 \mathrm{ppm} \mathrm{CCl}_{4}$ (table 1).

\section{RATIO OF LIVER TO BODY WEIGHT AND LIVER} TRIGLYCERIDE

The ratio of liver to body weight increased with increasing exposure concentration of $\mathrm{CCl}_{4}$ in ethanol treated and one day food deprived rats, and was also increased, but to a lesser degree, in non-treated rats (table 2).

Liver triglyceride concentrations were significantly increased at $10 \mathrm{ppm}$ or higher concentration of $\mathrm{CCl}_{4}$ in all rats (table 2 ).

\section{HISTOPATHOLOGICAL FINDINGS}

No alterations were found in the livers of non-treated rats exposed to 5 and $10 \mathrm{ppm} \mathrm{CCl}_{4}$, whereas fat deposits (data not shown) were found after exposure to 25,50 , and $100 \mathrm{ppm} \mathrm{CCl}_{4}$. Negligible ballooned hepatocytes and necrotic hepatocytes were seen in the livers of non-treated rats exposed to $\geqslant 25 \mathrm{ppm}$ $\mathrm{CCl}_{4}$ and of ethanol treated, and food deprived rats exposed to $5 \mathrm{ppm} \mathrm{CCl}_{4}$ (table 3). Ballooned hepatocytes were mainly seen in mid-zonal areas when ethanol treatment was combined with exposure to $10 \mathrm{ppm} \mathrm{CCl}_{4}$ and in centrilobular areas when food deprivation was combined with exposures to 10 and $25 \mathrm{ppm} \mathrm{CCl}_{4}$. Necrotic hepatocytes were found in centrilobular areas of ethanol treated rats exposed to more than $25 \mathrm{ppm} \mathrm{CCl}_{4}$ and of food deprived rats exposed to more than $50 \mathrm{ppm} \mathrm{CCl}_{4}$. Only a few ballooned and necrotic hepatocytes were seen in periportal areas of both ethanol treated and food deprived rats after $10 \mathrm{ppm}$ or higher exposure to $\mathrm{CCl}_{4}$ (table 3).

The figure shows photomicrographs of liver sections from ethanol treated rats (figures $A$ and $B$ ) and one day food deprived rats (figures $C$ and $D$ ). Livers from ethanol treated rats showed scattered ballooning degeneration in mid-zonal areas at exposure to $10 \mathrm{ppm} \mathrm{CCl}_{4}$ (figure $\mathrm{A}$ ) whereas necrotic hepatocytes surrounded with ballooned hepatocytes in centrilobular areas were seen on exposure to 25 $\mathrm{ppm} \mathrm{CCl}_{4}$ (figure B). Liver from one day food deprived rats showed ballooning degeneration mainly in centrilobular areas on exposure to $25 \mathrm{ppm}$ $\mathrm{CCl}_{4}$ (figure $\mathrm{C}$ ) and necrotic hepatocytes were also found in centrilobular areas with ballooned hepatocytes on exposure to $50 \mathrm{ppm} \mathrm{CCl}_{4}$ (figure D).

\section{ETHANOL CONSUMPTION AND $\mathrm{CCL}_{4}$ INDUCED} HEPATOXICITY

Table 4 presents the results. Plasma GOT and GPT activities were unchanged in rats treated with $0,0.5$, and $1.0 \mathrm{~g}$ ethanol, but increased in rats treated with $2.0 \mathrm{~g}$ ethanol.

Ethanol treatment itself increased liver MDA concentration at the 1.0 or $2.0 \mathrm{~g}$ dose. Carbon tetrachloride exposure raised liver MDA concentration only in rats given $2.0 \mathrm{~g}$ ethanol.

\section{Discussion}

A considerable amount of research on $\mathrm{CCl}_{4}$ induced hepatic damage has been conducted. ${ }^{1-3}$ Adams et al investigated species differences in the hepatotoxicity of $\mathrm{CCl}_{4}$ and reported that no detectable injury was noticed in rat liver exposed to $50 \mathrm{ppm} \mathrm{CCl}_{4}$ for seven hours. ${ }^{25}$ Uemitsu et al proposed that the no effect level of $\mathrm{CCl}_{4}$ on GOT activity is $500 \mathrm{ppm} \mathrm{CCl}_{4} \cdot{ }^{26}$ In the present study, plasma GOT and GPT activities, and liver MDA contents were not changed by exposure to $100 \mathrm{ppm} \mathrm{CCl}_{4}$ for eight hours in non-treated rats. The accumulation of triglycerides and fat deposits were seen, however, after exposure to $25 \mathrm{ppm} \mathrm{CCl}_{4}$.

Consumption of ethanol and food deprivation potentiated $\mathrm{CCl}_{4}$ induced hepatotoxicity. ${ }^{27-30}$ Our study shows that transaminase activities increased at $\mathrm{CCl}_{4}$ concentrations of $10 \mathrm{ppm}$ or higher in ethanol treated rats and of $25 \mathrm{ppm}$ or higher in one day food deprived rats. Liver MDA concentrations had increased already at $5 \mathrm{ppm} \mathrm{CCl}_{4}$ in ethanol treated rats and at $25 \mathrm{ppm}$ in one day food deprived rats. In agreement with these biochemical findings, significant histopathological changes were seen in both ethanol treated and one day food deprived rats at exposures of $10 \mathrm{ppm}$ and $25 \mathrm{ppm} \mathrm{CCl}_{4}$ respectively. These results indicate that both consumption of ethanol and deprivation of food potentiate $\mathrm{CCl}_{4}$ induced hepatotoxicity at low $\mathrm{CCl}_{4}$ concentrations: ethanol potentiates the hepatotoxicity at $\mathrm{CCl}_{4}$ concentrations as low as $5 \mathrm{ppm}$ and $10 \mathrm{ppm}$. These are the proposed TLV concentrations in the United States and Japan. ${ }^{1617}$ This indicates that heavy drinkers are at risk when exposed to $\mathrm{CCl}_{4}$ at TLV concentrations.

Workers engaged in treatment of waste water were found to be exposed to comparatively high concentration of $\mathrm{CCl}_{4}$ (up to $39.3 \mathrm{ppm}$ ) or chloroform (up to $45.2 \mathrm{ppm}$ ) when handling organic solvents. ${ }^{4}$ Thus these workers should be no more than temperate drinkers to avoid becoming intoxicated by $\mathrm{CCl}_{4}$.

Lipid peroxide concentrations were estimated by MDA formation. ${ }^{31}{ }^{32} \mathrm{~A}$ poor correlation between liver MDA concentrations and plasma transaminase activities in $\mathrm{CCl}_{4}$ exposed rats was found. Liver MDA concentration increased linearly with plasma 
Table 3 Histological evaluation of the effects of exposure to $\mathrm{CCl}_{4}$ on liver

\begin{tabular}{|c|c|c|c|c|}
\hline \multirow[b]{2}{*}{ Treatment } & \multirow[b]{2}{*}{$\mathrm{CCl}_{4}(\mathrm{ppm})$} & \multicolumn{3}{|c|}{ Centrilobular areas } \\
\hline & & $N o^{\star}$ & $B H \dagger(\%)$ & $\mathrm{NH} \dagger(\%)$ \\
\hline None & $\begin{array}{r}5 \\
10 \\
25 \\
50 \\
100\end{array}$ & $\begin{array}{ll}153 & (1) \\
152 & (2) \\
154 & (2) \\
152 & (3) \\
149 & (2)\end{array}$ & $\begin{array}{ll}0 & \\
0 & \\
1.0 & (1.0) \\
0.7 & (0.5) \\
0.2 & (0.3)\end{array}$ & $\begin{array}{l}0 \\
0 \\
0 \\
0 \\
0\end{array}$ \\
\hline Three weeks ethanol treatment & $\begin{array}{r}5 \\
10 \\
25 \\
50 \\
100\end{array}$ & $\begin{array}{ll}152 & (2) \\
153 & (2) \\
155 & (1) \\
153 & (2) \\
154 & (2)\end{array}$ & $\begin{aligned} 0.5 & (0.5) \\
11.2 & (7.0) \\
15.8 & (7.0) \\
5.6 & (3.5) \\
3.0 & (0.6)\end{aligned}$ & $\begin{array}{cc}0 & \\
0.7 & (1.1) \\
75.0 & (7.2) \\
83.9 & (10.8) \\
94.1 & (3.5)\end{array}$ \\
\hline One day food deprivation & $\begin{array}{r}5 \\
10 \\
25 \\
50 \\
100\end{array}$ & $\begin{array}{ll}153 & (1) \\
148 & (6) \\
150 & (5) \\
152 & (3) \\
151 & (2)\end{array}$ & $\begin{array}{r}1.1(1.0) \\
14.9(4.7) \\
35.0(10 \cdot 1) \\
21.5(7.9) \\
18.6(11.8)\end{array}$ & $\begin{array}{ll}0 & \\
0 & \\
8 \cdot 0 & (7 \cdot 0) \\
45 \cdot 7 & (31 \cdot 5) \\
72 \cdot 8 & (14 \cdot 0)\end{array}$ \\
\hline
\end{tabular}

*Values are Nos of normal, ballooned, and necrotic hepatocytes among 160 hits of areas and shown as mean (SD) for four rats.

†Ballooned hepatocytes (BH); values are \% of Nos of hepatocytes.

$\ddagger$ Necrotic hepatocytes $(\mathrm{NH})$; values are \% of Nos of hepatocytes.

GPT activity up to $1000 \mathrm{IU} / 1$, but not further. The MDA concentration ceased to increase when exposure reached concentrations of 10 and $25 \mathrm{ppm}$ $\mathrm{CCl}_{4}$ in ethanol treated rats, and 25 and $50 \mathrm{ppm}$ in one day food deprived rats-that is, when hepatic cells changed from ballooning to necrosis. The basis for this discrepancy is not clear. Plasma MDA concentration tended to rise after liver MDA concentration reached a maximum or began to decrease (table 1), suggesting that liver MDA may leak into the blood from necrotic hepatic cells, in agreement with the view of Harris et al. ${ }^{33}$

As ethanol consumption and food deprivation induce $\mathrm{P}-450 \mathrm{IIE} 1$, which contributes to $\mathrm{CCl}_{4}$ bioactivation, ${ }^{10-15}$ these treatments seem to increase the rate of lipid peroxidation. On the other hand, both consumption of ethanol and food deprivation decreased liver GSH concentration, and therefore impaired the scavenging of toxic free radicals. ${ }^{34-36}$ Thus the mechanism whereby consumption of ethanol and food deprivation potentiate $\mathrm{CCl}_{4}$ hepatotoxicity can be an increase in the generation of radical metabolites or a decrease in the GSH concentration of liver, or both. Although the concentration of GSH in liver in one day food deprived rats $(1.05$ (SD 0.11) $\mathrm{mg} / \mathrm{g}$ liver) was less than that in ethanol treated rats $(1.56$ (SD 0.16$) \mathrm{mg} / \mathrm{g}$ liver) in the present study, the effect of ethanol on $\mathrm{CCl}_{4}$ hepatotoxicity was more prominent than that of one day food deprivation. This indicates that lipid peroxidation and the metabolic activation of $\mathrm{CCl}_{4}$ were more important than detoxication by GSH.

In recent years physiologically based pharmaco- kinetic models for inhaled $\mathrm{CCl}_{4}$ have been developed. ${ }^{338}$ Uemitsu reported that $\mathrm{CCl}_{4}$ metabolism in vivo was perfusion limited at inhaled concentrations below around $100 \mathrm{ppm}$ and was saturated at inhaled concentrations above $100 \mathrm{ppm}$ in naive rats. ${ }^{37}$ This means that the metabolism of $\mathrm{CCl}_{4}$ is not rate limited by a Michaelis-Menten mechanism, but by perfusion. In the present study, however, the $\mathrm{CCl}_{4}$ hepatotoxicity was potentiated at $\mathrm{CCl}_{4}$ concentrations below $25 \mathrm{ppm}$ by chronic ethanol treatment or one day food deprivation. Moreover, the degree of hepatic injury caused by $\mathrm{CCl}_{4}$ was more severe in ethanol treated rats than in one day food deprived rats. These results suggest that the metabolism of $\mathrm{CCl}_{4}$ may be controlled by a metabolic step at a concentration as low as 25 ppm.

It is of practical significance that information is obtained through animal studies of low dose inhalation exposure to $\mathrm{CCl}_{4}$. With the help of physiologically based pharmacokinetic models animal data can be scaled to estimate human response. ${ }^{39} 40$

This research was supported in part by a grant in aid for encouragement of young scientists (B) from the Japanese Ministry of Education, Science, and Culture.

Requests for reprints to: Hisayoshi Ikatsu, Department of Hygiene, Shinshu University School of Medicine, Asahi 3-1-1, Matsumoto-shi 390, Japan. 


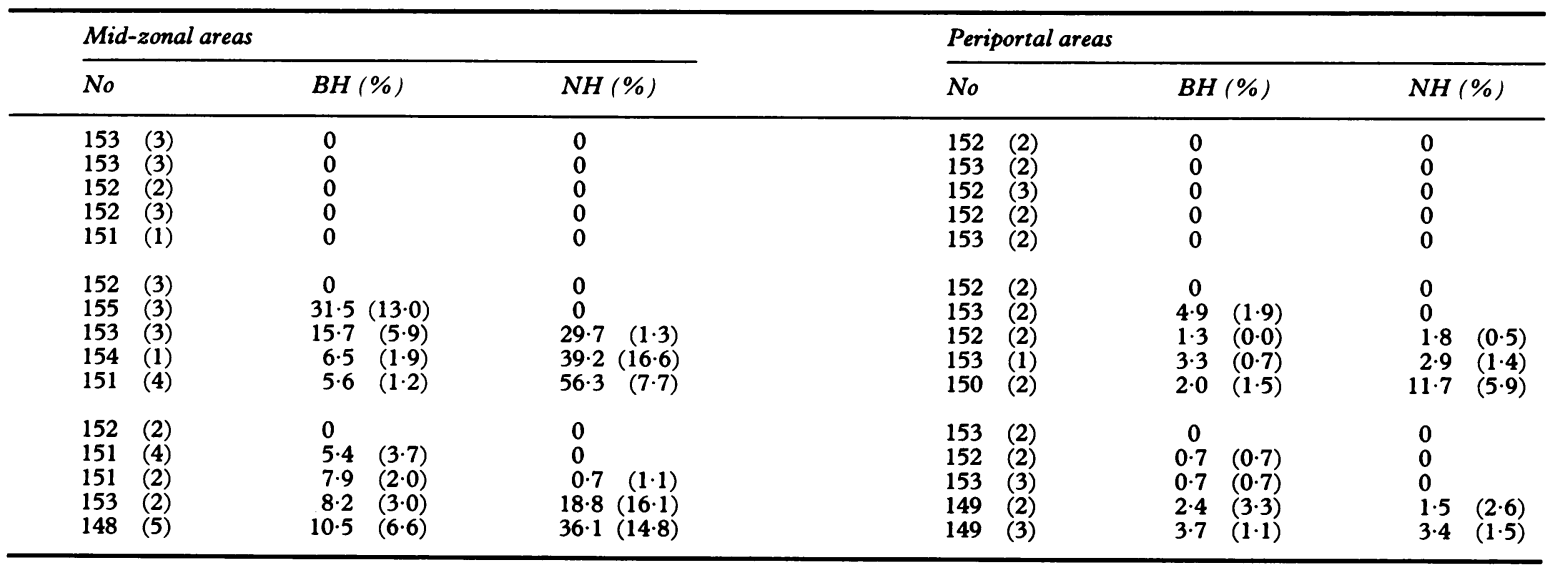
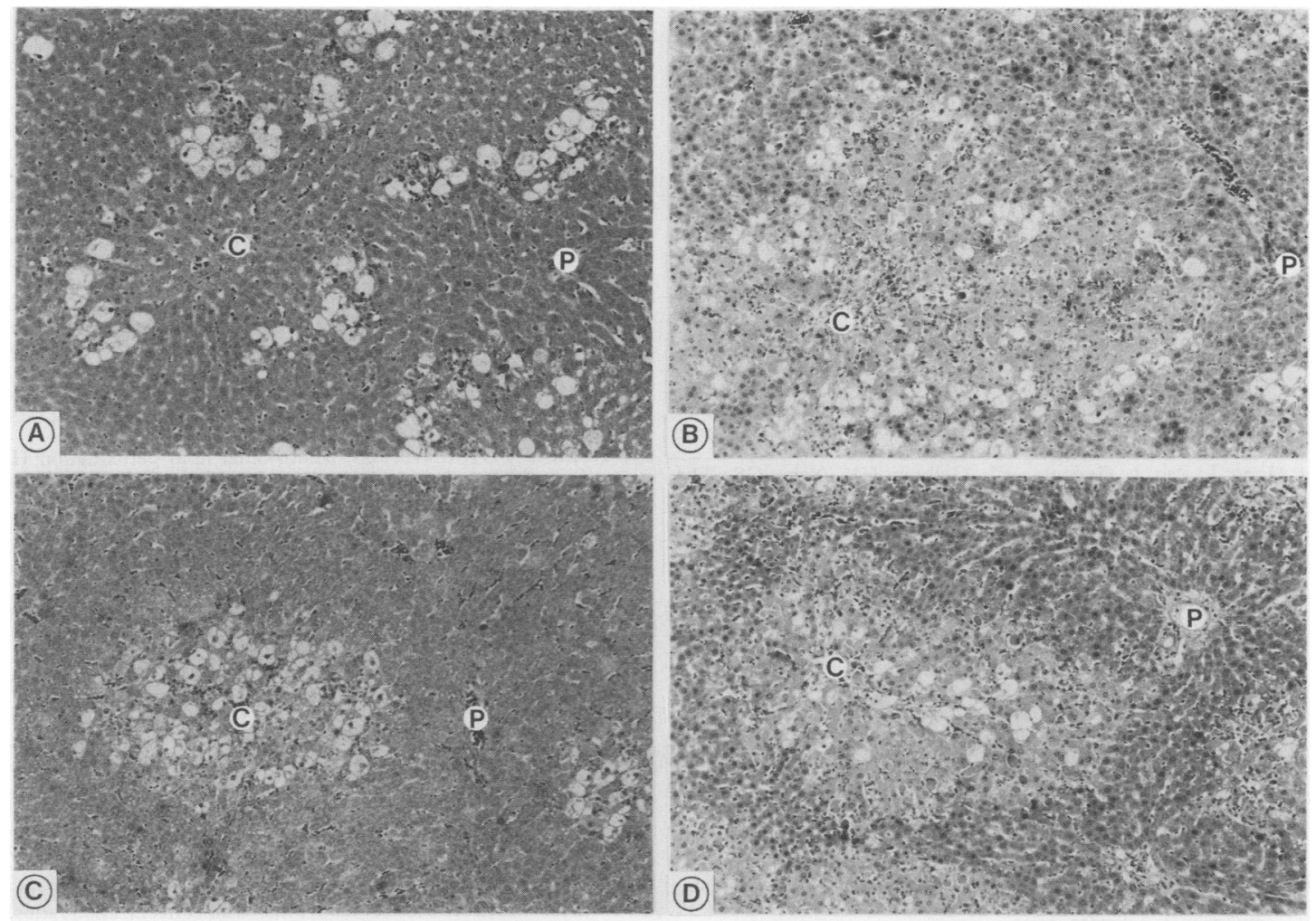

Figure Hepatic histopathological appearance $(\times 33)$ after exposure to $C C l_{4}(A)$ Liver injury in an ethanol treated rat at exposure to $10 \mathrm{ppm} \mathrm{CCl}$ (GPT $338 \mathrm{IU} / \mathrm{l})$. Ballooned hepatocytes are seen in mid-zonal areas. (B) Liver injury in an ethanol treated rat at exposure to $25 \mathrm{ppm} \mathrm{CCl}_{4}(\mathrm{GPT} 1960 \mathrm{IU} / \mathrm{l})$. Necrotic hepatocytes surrounded with ballooned hepatocytes in centrilobular areas are seen. (C) Liver injury in a one day food deprived rat exposed to $25 \mathrm{ppm} C C \mathrm{~L}_{4}(\mathrm{GPT}$ $330 \mathrm{IU}(\mathrm{l})$. Ballooned hepatocytes occur frequently in centrilobular areas. (D) Liver injury in a one day food deprived rat exposed to $50 \mathrm{ppm} \mathrm{CCl}$ (GPT $1710 \mathrm{IU} / \mathrm{l})$. Necrotic hepatocytes with ballooned hepatocytes in centrilobular areas are seen. $C=$ Central vein, $P=$ portal triad. 
Table 4 Effect of three weeks ethanol consumption on plasma transaminase activity and liver MDA concentration after exposure to $\mathrm{CCl}_{4}$

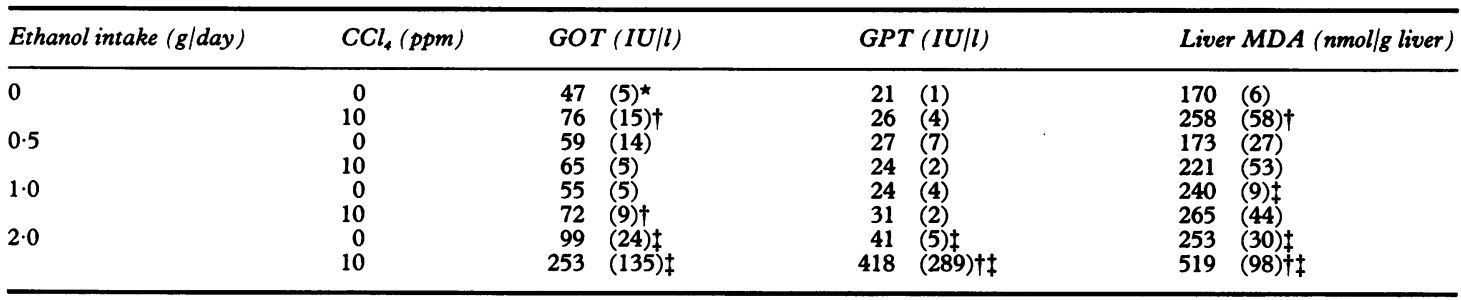

$\star+$ See footnotes in table 1 .

$\ddagger$ Significantly different from no ethanol group $(p<0.05)$.

1 Klaassen CD, Plaa GL. Relative effects of various chlorinated hydrocarbons on liver and kidney function in mice. Toxicol Appl Pharmacol 1966;9:139-51.

2 Brattin WJ, Glende EA Jr, Recknagel RO. Pathological mechanisms in carbon tetrachloride hepatotoxicity. Journal of Free Radicals in Biology and Medicine 1985;1:27-38.

3 Fowler JSL. Chlorinated hydrocarbon toxicity in the fowl and duck. J Comp Pathol 1970;80:465-71.

4 Ikatsu H, Nakajima T, Okino T, Murayama N. Health care of workers engaged in waste water treatment. 1) The exposure conditions of organic solvents in workers engaged in waste water treatment. Japanese Journal of Industrial Health 1989;31:355-62. (In Japanese.)

5 Sipes GI, Krishna G, Gillette JR. Bioactivation of carbon tetrachloride, chloroform, and bromotrichloromethan: Role of cytochrome P-450. Life Sci 1977;20:1541-8.

6 Kalyanaraman B, Mason RP, Perez-Reyes E, Chignell CF, Wolf CR, Philpot RM. Characterization of the free radical formed in aerobic microsomal incubations containing carbon tetrachloride and NADPH. Biochem Biophys Res Commun 1979;89:1065-72.

7 Slater TF. Free-radical mechanisms in tissue injury. Biochem $\mathrm{J}$ 1984;222:1-15.

8 Thomas PE, Reik LM, Mains S, Bandiera S, Ryan DE, Levin W. Antibodies as probes of P-450 isozymes. Adv Exp Med Biol 1986;197:95-106.

9 Nebert DW, Gonzalez FJ. P-450 genes: structure, evolution, and regulation. Annual Review of Biochemistry 1987;56: 945-93.

10 Johansson I, Ekström G, Scholte B, Puzycki D, Jörnvall H, Ingelman-Sundberg $M$. Ethanol-, fasting- and acetoneinducible cytochrome $P-450$ in rat liver. Regulation and characteristics of enzymes belonging to the IIB and IIE gene subfamilies. Biochemistry 1988;27:1925-34.

11 Hong J, Pan J, Gonzalez FJ, Gelboin HV, Yang CS. The induction of a specific form of cytochrome P-450 (P-450j) by fasting. Biochem Biophys Res Commun 1987;142:1077-83.

12 Johansson I, Ingelman-Sundberg $M$. Carbon tetrachlorideinduced lipid peroxidation dependent on an ethanol-inducible form of rabbit liver microsomal cytochrome $\mathrm{P}-450$. FEBS Lett 1985;183:265-9.

13 Nakajima T, Elovaara S, Park SS, Gelboin HV, Hietanen E, Vainio H. Immunochemical characterization of cytochrome P-450 isozymes responsible for benzene oxidation in the rat liver. Carcinogenesis 1989;10:1713-7.

14 Nakajima T, Elovaara E, Park SS, Gelboin HV, Hietanen E, Vainio $\mathrm{H}$. Monoclonal antibody-directed characterization of benzene, ethoxyresorufin and pentoxyresorufin metabolism in rat liver microsomes. Biochem Pharmacol 1990;40:1255-61.

15 Nakajima T, Wang RS, Elovaara E, et al. Monoclonal antibodydirected characterization of cytochrome P-450 isozymes responsible for toluene metabolism in rat liver. Biochem Pharmacol 1991;41:395-404.

16 American Conference of Governmental Industrial Hygienists. Threshold limit values and biological exposure indices for 1988-9. Cincinnati: ACGIH, 1988.

17 Japan Association of Industrial Health. Recommendation of threshold limit values. Japanese Journal of Industrial Health 1989;31:257-77. (In Japanese.)

18 Sabourin PJ, Bechtold WE, Griffith WC, Birnbaum LS, Lucier $G$, Henderson RF. Effect of exposure concentration, exposure rate, and route of administration on metabolism of benzene by F344 rats and $\mathrm{B} \mathrm{C} 3 \mathrm{~F}_{1}$ mice. Toxicol Appl Pharmacol 1989;99:421-44.

19 DeCarli LM, Lieber CS. Fatty liver in the rat after prolonged intake of ethanol with a nutritionally adequate liquid diet. J Nutr 1967;91:331-6.

20 Uchiyama $M$, Mihara $M$. Determination of malonaldehyde precursor in tissues by thiobarbituric acid test. Anal Biochem 1978;86:271-8.
21 Jose PJ, Slater TF. Increased concentrations of malonaldehyde in the livers of rats treated with carbon tetrachloride. Biochem $J$ 1972;128:141.

22 Nair V, Turner GA. The thiobarbituric acid test for lipid peroxidation: structure of the adduct with malondialdehyde. Lipids 1984;19:804-5.

23 Mitchell JR, Jollow DJ, Potter WZ, Davis DC, Gillette JR, Brodie BB. Acetaminophen-induced hepatic necrosis. I. Role of drug metabolism. J Pharmacol Exp Ther 1973;187:185-94.

24 Hewitt WR, Miyajima H, Cote MG, Plaa GL. Acute alteration of chloroform-induced hepato- and nephrotoxicity by n-hexane, methyl n-butyl ketone, and 2,5-hexanedione. Toxicol Appl Pharmacol 1980;53:230-48.

25 Adams EM, Spencer HC, Rowe VK, McCollister DD, Irish DD. Vapor toxicity of carbon tetrachloride determined by experiments on laboratory animals. Archives of Industrial Hygiene and Occupational Medicine 1952;6:50-66.

26 Uemitsu N, Minobe Y, Nakayoshi H. Concentration-TimeResponse relationship under condition of single inhalation of carbon tetrachloride. Toxicol Appl Pharmacol 1985;77:260-6.

27 Teschke R, Vierke W, Gellert J. Effect of ethanol on carbon tetrachloride levels and hepatotoxicity after acute carbon tetrachloride poisoning. Arch Toxicol 1984;56:78-82.

28 Strubelt O, Obermeier F, Siegers CP, Volpel M. Increased carbon tetrachloride hepatotoxicity after low-level ethanol consumption. Toxicology 1978;10:261-70.

29 Días Gómez MI, De Castro CR, De Ferreyra EC, D'Acosta N, Fenos OM, Castro JA. Mechanistic studies on carbon tetrachloride hepatotoxicity in fasted and fed rats. Toxicol Appl Pharmacol 1975;32:101-8.

30 Jaeger RJ, Conolly RB, Murphy SD. Short-term inhalation toxicity of halogenated hydrocarbons. Effects on fasting rats. Arch Environ Health 1975;30:26-30.

31 Kornbrust DJ, Mavis RD. Microsomal lipid peroxidation II. Stimulation by carbon tetrachloride. Mol Pharmacol 1980;17:408-14.

32 De Groot H, Noll T. Halomethane hepatotoxicity: Induction of lipid peroxidation and inactivation of cy tochrome $P-450$ in rat liver microsomes under low oxygen partial pressures. Toxicol Appl Pharmacol 1989;97:530-7.

33 Harris RN, Ratnayake JH, Garry VF, Anders MW. Interactive hepatotoxicity of chloroform and carbon tetrachloride. Toxicol Appl Pharmacol 1982;63:281-91.

34 Macdonald CM, Dow J, Moore MR. A possible protective role for sulfhydryl compounds in acute alcoholic liver injury. Biochem Pharmacol 1977;26:1529-31.

35 Tateishi N, Higashi T, Shinya S, Naruse A, Sakamoto Y. Studies on the regulation of glutathione level in rat liver. J Biochem 1974;75:93-103.

36 Charles S, Lieber MD. Metabolic effect of ethanol and its interaction with other drugs, hepatotoxic agents, vitamins, and carcinogens: A 1988 update. Semin Liver Dis 1988;8: $47-68$.

37 Uemitsu N. Inhalation pharmacokinetics of carbon tetrachloride in rats based on arterial blood: inhaled air concentration ratios. Toxicol Appl Pharmacol 1986;83:20-29.

38 Paustenbach DJ, Clewell HJ, Gargas ML, Andersen ME. A physiologically based pharmacokinetic model for inhaled carbon tetrachloride. Toxicol Appl Pharmacol 1988;96: 191-211.

39 Andersen ME. A physiologically based toxicokinetic description of the metabolism of inhaled gases and vapors: Analysis at steady state. Toxicol Appl Pharmacol 1981;60:509-26.

40 Ramsey JC, Andersen ME. A physiologically based description of the inhalation pharmacokinetics of styrene in rats and man. Toxicol Appl Pharmacol 1984;73:159-75. 